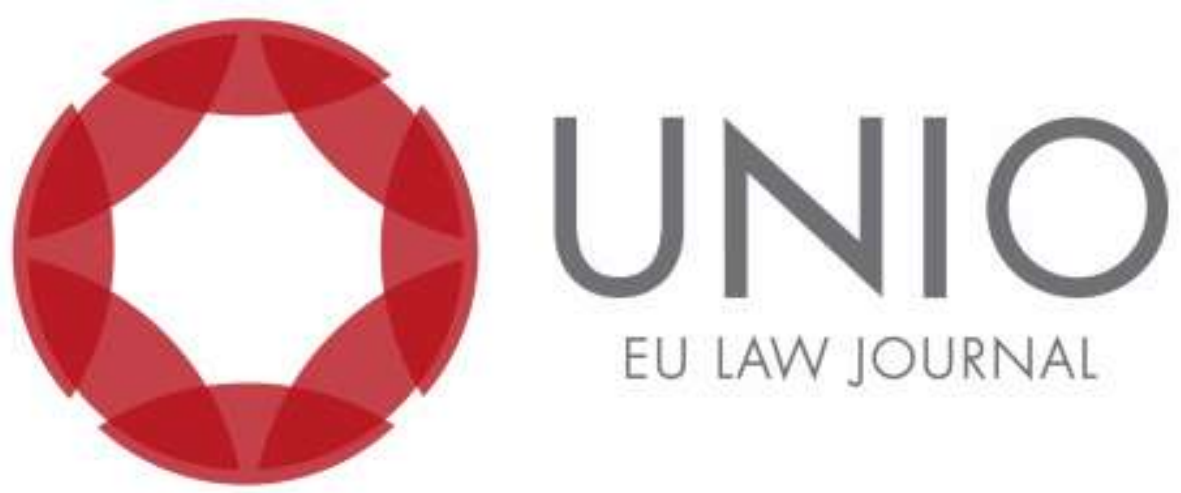

The European arrest warrant in the case law of the Court of Justice

\author{
Helena Patricio \\ Judge at the Civil Court of Ílhavo \\ and former Legal Secretary at the Court of Justice of the European Union
}

\begin{abstract}
A key factor in the creation of a European area of freedom, security and justice is the principle of mutual recognition, which the Framework Decision 2002/584/JHA of 13 June 2002, for the first time, comprehensively implemented in the field of judicial cooperation in criminal matters. The Court of Justice of the European Union has greatly contributed to the understanding of the Framework Decision, accentuating its goals and enhancing its guiding principles, which are the mutual recognition of judgments in the different Member States of the European Union and mutual trust that should settle among them, for the creation of the said area. The West judgment of 28 June 2012, C-192/12 PPU, on urgent preliminary ruling procedure, aptly illustrates the impact of this case law, highlighting the role of this procedure, implemented on 1 March 2008.
\end{abstract}

KEYWORDS: judicial cooperation - principle of mutual recognition - European arrest warrant-Judgment West-Cunha Rodrigues.

\title{
I. Introduction
}

In the field of judicial cooperation in criminal matters, the European arrest warrant theme appears as unavoidable, representing «the first concrete measure in the field of criminal law implementing the principle of mutual recognition which the European Council referred to 
as the 'cornerstone' of judicial cooperation», ${ }^{1}$ in October 1999, in Tampere. The consecration of the European arrest warrant appeared in the European legal order after the events in the United States 11 September 2001 - with the main objective of making the Union an area of freedom, security and justice by ensuring the free movement of persons in safety and respect for their fundamental rights.

Therefore, it is relevant to mention, albeit perfunctorily, the most significant notes of the European arrest warrant as a mechanism for cooperation between the Member States (legal framework, meaning and objectives). It is also appropriate to run through the case law of the Court of Justice in order to examine the practical difficulties that have been presented to its enforcers (addressed issues). Finally, given the scope of application of this mechanism, it is very important to address, synthetically, the urgent preliminary ruling procedure (application criteria and procedure).

\section{European arrest warrant as a cooperation mechanism: legal framework, meaning and objectives}

The European arrest warrant legal system has replaced the previous system of extradition, to facilitate the recognition, by means of minimum controls, the request for surrender of a person for the purpose of serving a sentence or the execution of criminal proceedings, promoting the implementation of a dialogue directly between the judicial authorities of the Member States concerned. ${ }^{2}$ As explained by the European legislator, «traditional cooperation relations which have prevailed up till now between Member States should be

\footnotetext{
${ }^{1}$ Paragraph 6 of the Council Framework Decision 2002/584/JHA of 13 June 2002 on the European arrest warrant and the surrender procedures between Member States, published in the Official Journal of the European Communities on 18 July 2002 (OJ L 190, 18.7.2002).

${ }^{2}$ Member States may continue to conclude and implement bilateral and multilateral agreements to facilitate and simplify the procedures for surrender but cannot affect relations with other Member States, which are not party to those agreements - Article 31(2) of Framework Decision 2002/584/JHA. Regarding the relationship between the European arrest warrant and extradition cf. Sophie Laugier-Deslandes, "Les incidences de la création du mandat d'arrêt européen sur les conventions d'extradition", in Annuaire français de droit international, vol. 48, 2002, 695-714.
} 
replaced by a system of free movement of judicial decisions in criminal matters, covering both pre-sentence and final decisions, within an area of freedom, security and justice». ${ }^{3}$

The European arrest warrant was adopted by the Council Framework Decision 2002/584/JHA of 13 June $2002,{ }^{4}$ on the European arrest warrant and the surrender procedures between Member States, having been modified by the Council Framework Decision 2009/299/JHA of 26 February 2009, ${ }^{5}$ which amended at the same time Framework Decision 2005/214/JHA, ${ }^{6}$ Framework Decision 2006/783/JHA, ${ }^{7}$ Framework Decision 2008/909/JHA ${ }^{8}$ and Framework Decision 2008/947/JHA, ${ }^{9}$ strengthening the procedural rights of persons and fostering the application of the principle of mutual recognition of decisions rendered in absentia.

The legislative amendment relates to the introduction of an Article 4-a thereof, concerning «Decisions rendered following a trial at which the person did not appear in person», having eliminated, as a result, paragraph 1 of Article 5, in which this matter was treated in less detail.

\footnotetext{
${ }^{3}$ Paragraph 5 of Framework Decision 2002/584/JHA.

${ }^{4}$ The Framework Decision 2002/584/JHA was adopted pursuant to Title VI of the Treaty on European Union then in force, integrating the Third Pillar established by the Maastricht Treaty. It entered into force on 7 August 2002 and the deadline for transposition in the Member States ended on 31 December 2003.

${ }^{5}$ In turn, the Framework Decision 2009/299/JHA was published in the Official Journal on 27 March 2009 (OJ L 81, 27.3.2009) and entered into force the following day. The deadline for transposition in the Member States ended on 28 March 2011.

${ }^{6}$ Council Framework Decision 2005/214/JHA of 24 February of 2005 on the application of the principle of mutual recognition to financial penalties, OJ L 76/16 (22.03.2005), transposed into national law by Law 93/2009 of 1 September (DR I, 169, 1 September 2009).
}

${ }^{7}$ Council Framework Decision 2006/783/JHA of 6 October 2006 on the application of the principle of mutual recognition to confiscation orders, OJ L $328 / 59$ (24.11.2006), transposed into national law by Law 88/2009 of 31 August (DR I, 168, 31 August 2009).

${ }^{8}$ Council Framework Decision 2008/909/JHA of 27 November 2008 on the application of the principle of mutual recognition to judgments in criminal matters imposing custodial sentences or measures involving deprivation of liberty for the purpose of their enforcement in the European Union, OJ L $327(05.12 .2008,27)$.

${ }^{9}$ Council Framework Decision 2008/947/JHA of 27 November 2008 on the application of the principle of mutual recognition to judgments and probation decisions with a view to the supervision of probation measures and alternative sanctions, OJ 337/102 (16.12.2008). 
Pursuant to Article 1(1), the Framework Decision 2002/584/JHA defines the European arrest warrant as «a judicial decision issued by a Member State with a view to the arrest and surrender by another Member State of a requested person, for the purposes of conducting a criminal prosecution or executing a custodial sentence or detention order».

According to the second paragraph of the same Article 1, «Member States shall execute any European arrest warrant on the basis of the principle of mutual recognition and in accordance with the provisions of this Framework Decision».

Framework Decision 2002/584/JHA has been transposed into the national legal order by Law 65/2003, of 23 August 2003, which approved the European arrest warrant legal system.

Under the heading «Concept and effects», Article 1(1) of the same law defines the European arrest warrant as «a judicial decision issued by a Member State with a view to arrest and surrender by another Member State of a person sought for purposes of criminal prosecution or executing a custodial sentence or detention order». Paragraph 2 of the same provision states that the warrant «is executed based on the principle of mutual recognition and in accordance with the provisions of this Law and the Council Framework Decision 2002/584/JHA of 13 June».

It is clear from these provisions that the European arrest warrant is aimed at achieving the prosecution or execution of a custodial sentence or measure involving deprivation of liberty, where the offenses are punishable by custodial sentence or measure involving deprivation of liberty of at least 12 months, or with the purpose of executing a custodial sentence or measure involving deprivation of liberty, provided that the penalty imposed is no less than 4 months - Article 2(1) of the Framework Decision 2002/584/JHA and Article 2(1) of Law 65/2003, of 23 August. 


\section{Case law of the Court of Justice of the European Union in this area}

1. The Court of Justice of the European Union (CJEU) had the opportunity to look into the Framework Decision 2002/584/JHA on several occasions, analysing it for the first time in the year 2007. Indeed, in the famous Judgment Advocaten voor de Wereld, ${ }^{10}$ the Court of Justice examined the formal and substantive validity of the Framework Decision 2002/584/JHA, concluding that the consideration of the questions raised had revealed no factor capable of affecting it.

First, the Court of Justice stated its jurisdiction to interpret provisions of primary law, in this case Article 34 (2) (b) of the Treaty on European Union (TUE), as it was called upon to decide whether a framework decision had been properly adopted on the basis of that provision, concluding positively.

Secondly, the Court of Justice reaffirmed that, under Article 6 of the EU Treaty, the Union is founded on the rule of law and respect of fundamental rights as recognized by the European Convention on Human Rights, signed in Rome on 4 November 1950 and examined the Framework Decision on the principles of legality and equality. The Court of Justice concluded that Article 2 (2) of the Framework Decision, while suppressing the verification of double criminality for the offenses referred to therein, did not violate the principle of legality, nor the principle of equality. ${ }^{11}$

2. Subsequently, the Court of Justice was requested to review the Framework Decision 2002/584/JHA on ten other occasions ${ }^{12}$ having examined Article 4 (6) in the Judgment

\footnotetext{
${ }^{10}$ Cf. Judgment Advocaten voor de Wereld, 3 May 2007, Case C-303/05.

11 The Framework Decision 2002/584/JHA does not aim to harmonize the substantive criminal law of the Member States who are responsible for precisely defining the offenses and respective penalties. On the other hand, the Council considered, on the basis of the principle of mutual recognition and the high degree of trust and solidarity existing between the Member States, that the categories of offenses listed in Article 2(2), given their nature or that are punishable by a custodial sentence exceeding three years, justify by their severity and by endangering public order and security, the elimination of the verification of double criminality.

12 Two days after the Conference to honour Judge Cunha Rodrigues, the Court of Justice delivered a further judgment on this matter - Judgment Jeremy F., 30 May 2013, Case C-168/13 PPU -, responding to questions
} 
Koslowski, ${ }^{13}$ in the Judgment Wolzenburg ${ }^{14}$ and in the Judgment $B .{ }^{15}$ In this last Judgment the Court also analysed Article 5 of the Framework Decision therein, as well as in its Judgment Lopes da Silva, ${ }^{16}$ in which it interpreted this provision alongside with Article 18 of the Treaty on the Functioning of the European Union (TFEU).

from the French Conseil constitutionnel on the interpretation of Articles 27 (4) and 28 (3) (c) of the Framework Decision2002/584/JHA

${ }^{13}$ Cf. Judgment Koslowski, 17 July 2008, Case C-66/08. In its Judgment the Court considered Article 4(6) of the Framework Decision 2002/584/JHA, interpreting the concept of residence and highlighting the comparable situations (in French «resides ou demeure»). The Court concluded that «a requested person is 'resident' in the executing Member State when he has established his actual place of residence there and he is 'staying' there when, following a stable period of presence in that State, he has acquired connections with that State which are of a similar degree to those resulting from residence». The Court stated that «in order to ascertain whether there are connections between the requested person and the executing Member State which lead to the conclusion that that person is covered by the term 'staying' within the meaning of Article 4(6), it is for the executing judicial authority to make an overall assessment of various objective factors characterizing the situation of that person, including, in particular, the length, nature and conditions of his presence and the family and economic connections which that person has with the executing Member State».

${ }^{14}$ Cf. Judgment Wolzenburg, 5 October 2009, Case C-123/08. In its Judgment the Court of Justice revisited Article 4 (6) of the Framework Decision. The Court concluded that «a national of one Member State who is lawfully resident in another Member State is entitled to rely on the first paragraph of Article 12 EC against national legislation, such as the Law on the surrender of persons (Overleveringswet), of 29 April 2004, which lays down the conditions under which the competent judicial authority can refuse to execute a European arrest warrant issued with a view to the enforcement of a custodial sentence». The Court also concluded that «Article 4, paragraph 6 of the Framework Decision 2002/584/JHA of 13 June 2002 on the European arrest warrant and the surrender procedures between Member States must be interpreted as meaning that the Member State of enforcement cannot, and a condition on the length of stay in this state, making application of the ground for optional non-execution of a European arrest warrant under that provision to administrative requirements Further, as the possession of a residence permit for an indefinite period.». Finally, the Court held that «Article 12 EC is to be interpreted as not precluding the legislation of a Member State of execution under which the competent judicial authority of that State is to refuse to execute a European arrest warrant issued against one of its nationals with a view to the enforcement of a custodial sentence, whilst such a refusal is, in the case of a national of another Member State having a right of residence on the basis of Article 18(1) $\mathrm{EC}$, subject to the condition that that person has lawfully resided for a continuous period of five years in that Member State of execution».

${ }^{15}$ Cf. Judgment B., 21 October 2010, Case C-306/09. In its Judgment the Court of Justice once again studied Article 4 (6) and Article 5 of the Framework Decision. The Court held that «Articles 4 (6) and 5 (3) of Council Framework Decision 2002/584/JHA of 13 June 2002 on the European arrest warrant and the surrender procedures between Member States must be interpreted as meaning that, where the executing Member State has implemented Articles 5 (1) and Article 5 (3) of that framework decision in its domestic legal system, the execution of a European arrest warrant issued for the purposes of execution of a sentence imposed in absentia within the meaning of Article 5 (1) of the framework decision, may be subject to the condition that the person concerned, a national or resident of the executing Member State, should be returned to the executing State in order, as the case may be, to serve there the sentence passed against him, following a new trial organised in his presence in the issuing Member State».

${ }^{16}$ Cf. Judgment Lopes da Silva, 5 September 2012, Case C-42/11. In this Judgment the Court of Justice focused on Article 4 (6) of the Framework Decision 2002/584/JHA, interpreting it while taking into account the provisions of Article 18 of the Treaty on the Functioning of the European Union. The Court held that «Article 4 (6) of Council Framework Decision 2002/584/JHA (...), and Article 18 TFEU must be interpreted 
In the Judgment Santesteban Goicoechea ${ }^{17}$ the Court of Justice studied Articles 31 and 32 of the Framework Decision - and in the Judgment Leymann and Pustovarov ${ }^{18}$ the Court of

as meaning that, although a Member State may, in transposing Article 4 (6), decide to limit the situations in which an executing judicial authority may refuse to surrender a person who falls within the scope of that provision, it cannot automatically and absolutely exclude from its scope the nationals of other Member States staying or resident in its territory irrespective of their connections with it». The Court also recalled that «the national court is required, taking into consideration the whole body of domestic law and applying the interpretative methods recognised by it, to interpret that law, so far as possible, in the light of the wording and the purpose of Framework Decision 2002/584, with a view to ensuring that that framework decision is fully effective and to achieving an outcome consistent with the objective pursued by it».

${ }^{17}$ Cf. Judgment Santesteban Goicoechea, 12 August 2008, Case C-296/08 PPU. In this Judgment the Court of Justice focused on Articles 31 and 32 of the Framework Decision relating to its validity and to the application of the Convention relating to extradition between the Member States of the European Union approved by the Council on 27 September 1996, signed on the same date by all Member States, although it has only entered into force in that Member State after 1 January 2004.The Court of Justice concluded, firstly, that «Article 31 of Council Framework Decision 2002/584/JHA of 13 June 2002 on the European arrest warrant and the surrender procedures between Member States must be interpreted as referring only to the situation in which the European arrest warrant system is applicable, which is not the case where a request for extradition relates to acts committed before a date specified by a Member State in a statement made pursuant to Article 32 of that Framework Decision». Secondly, the Court held that «Article 32 of Framework Decision 2002/584 must be interpreted as not precluding the application by an executing Member State of the Convention relating to extradition between the Member States of the European Union drawn up by Council Act of 27 September 1996 and signed on that date by all the Member States, even where that convention became applicable in that Member State only after 1 January 2004».

${ }^{18}$ Cf. Judgment Leymann e Pustovarov, 1 December 2008, Case C-388/08 PPU. In this Judgment the Court focused on Article 27 of the Framework Decision, reflecting on the principle of specialty enshrined therein. The Court of Justice held that «in order to establish whether the offence under consideration is an 'offence other' than that for which the person was surrendered within the meaning of Article 27 (2) of Council Framework Decision 2002/584/JHA of 13 June 2002 on the European arrest warrant and the surrender procedures between Member States, requiring the implementation of the consent procedure referred to in Article 27 (3) (g) and 27 (4) of that Framework Decision, it must be ascertained whether the constituent elements of the offence, according to the legal description given by the issuing State, are those in respect of which the person was surrendered and whether there is a sufficient correspondence between the information given in the arrest warrant and that contained in the later procedural document. Modifications concerning the time or place of the offence are allowed, in so far as they derive from evidence gathered in the course of the proceedings conducted in the issuing State concerning the conduct described in the arrest warrant, do not alter the nature of the offence and do not lead to grounds for non-execution under Articles 3 and 4 of the Framework Decision». The Court also concluded that «in the circumstances of the main proceedings, a modification of the description of the offense, which relates to the category of drugs in question, is not, by itself, likely to typify an 'offense other' that for which the person was surrendered within the meaning of Article 27, paragraph 2 of Decision - Table 2002/584». Finally, the Court of Justice held that «the exception in Article 27 (3) (c) of Framework Decision 2002/584 must be interpreted as meaning that, where there is an 'offence other' than that for which the person was surrendered, consent must be requested, in accordance with Article 27 (4) of the Framework Decision, and obtained if a penalty or a measure involving the deprivation of liberty is to be executed. The person surrendered can be prosecuted and sentenced for such an offence before that consent has been obtained, provided that no measure restricting liberty is applied during the prosecution or when judgment is given for that offence. The exception in Article 27(3) (c) does not, however, preclude a measure restricting liberty from being imposed on the person surrendered before consent has been obtained, where that restriction is lawful on the basis of other charges which appear in the European arrest warrant». 
Justice focused on Article 27 of the Framework Decision. In the Judgment Mantello ${ }^{19}$ the Court of Justice studied the concept of «same acts» referred to in Article 3 (2) of the Framework Decision. In the Judgment West ${ }^{20}$ the Court of Justice interpreted Article 28 of the Framework Decision on the need for consent of the executing Member State if successive detention warrants are issued. In the Judgment Radu ${ }^{21}$ the Court of Justice examined the Framework Decision in the light of Articles 47 and 48 of the Charter of Fundamental Rights of the European Union and Article 6 of the European Convention on Human Rights. In the Judgment Melloni ${ }^{22}$ the Court of Justice interpreted Article 4 a (1), of the Framework Decision 2002/584/JHA, as amended by Framework Decision 2009/299/JHA, and did so in the light of Articles 47, 48 (2) and 53 of the Charter of Fundamental Rights of the European Union.

\footnotetext{
${ }^{19}$ Cf. Judgment Mantello, 16 November 2010, Case C-261/09. In this Judgment the Court held that «for the purposes of the issue and execution of a European arrest warrant, the concept of 'same acts' in Article 3 (2) of Council Framework Decision 2002/584/JHA of 13 June 2002 on the European arrest warrant and the surrender procedures between Member States constitutes an autonomous concept of European Union law». And also that «in circumstances such as those at issue in the main proceedings where, in response to a request for information within the meaning of Article 15 (2) of that Framework Decision made by the executing judicial authority, the issuing judicial authority, applying its national law and in compliance with the requirements deriving from the concept of 'same acts' as enshrined in Article 3 (2) of the Framework Decision, expressly stated that the earlier judgment delivered under its legal system did not constitute a final judgment covering the acts referred to in the arrest warrant issued by it and therefore did not preclude the criminal proceedings referred to in that arrest warrant, the executing judicial authority has no reason to apply, in connection with such a judgment, the ground for mandatory non-execution provided for in Article 3 (2) of the Framework Decision».
}

${ }^{20}$ Cf. Judgment West, 28 June 2012, Case C-192/12 PPU.

${ }^{21}$ Cf. Judgment Radu, 29 January 2013, Case C-396/11. In this Judgment the Court concluded that the Framework Decision 2002/584/JHA, as amended by Framework Decision 2009/299/JHA, must be interpreted as meaning that the judicial enforcement authorities cannot refuse to execute a European arrest warrant issued for the purposes of criminal proceedings on the ground that the person requested has not been heard in the Member State of issue before this arrest warrant was issued.

${ }^{22}$ Cf. Judgment Melloni, 26 February 2013, Case C-399/11. In this Judgment the Court held that «Article 4 a (1) of Council Framework Decision 2002/584/JHA (...), as amended by Framework Decision 2009/299/JHA (...), must be interpreted as precluding the executing judicial authorities, in the circumstances specified in that provision, from making the execution of a European arrest warrant issued for the purposes of executing a sentence conditional upon the conviction rendered in absentia being open to review in the issuing Member State». And, also, that «Article 4 a (1) of Framework Decision 2002/584, as amended by Framework Decision 2009/299, is compatible with the requirements under Articles 47 and 48 (2) of the Charter of Fundamental Rights of the European Union». And finally, that «Article 53 of the Charter of Fundamental Rights of the European Union must be interpreted as not allowing a Member State to make the surrender of a person convicted in absentia conditional upon the conviction being open to review in the issuing Member State, in order to avoid an adverse effect on the right to a fair trial and the rights of the defense guaranteed by its constitution». 
Given the impossibility of analysing all of these decisions here, we will focus in the analysis of Judgment West, given the issues raised therein and since it was delivered in response to proceedings in an urgent preliminary ruling, whose characteristics will be highlighted.

3. In the Judgment West the Court of Justice interpreted for the first time, Article 28 of the Framework Decision concerning successive surrenders of the same person, subject to successive European arrest warrants, calling this situation the «chain of European arrest warrants». ${ }^{23}$

The factual situation was, briefly, as follows: Mr West was subject to three successive European arrest warrants for the theft of ancient and rare maps, committed in October 1999 and September 2000 in France, in February 2001 in Finland, and in August 2000 in Hungary. The first arrest warrant was issued by France in March 2005. Failing to be enforced, Mr West was tried and convicted in absentia, and a new arrest warrant was issued by the French judicial authorities, in August 2007, for the purposes of enforcing the imposed custodial sentence of 3 years.

The second arrest warrant was issued by the Finnish authorities in December 2009, for the purposes of executing a custodial sentence against Mr. West. The third arrest warrant was issued by the Hungarian judicial authorities in April 2010, for the purposes of criminal proceedings. The arrest warrants issued by the aforementioned French, Finnish and Hungarian judicial authorities were executed in the reverse order of their issue, having $\mathrm{Mr}$ West been surrendered by the United Kingdom authorities, his country of nationality and residence, to the Hungarian authorities. This surrender was not made subject to any condition. Mr. West was tried and convicted for the crimes of theft, and sentenced to a 16 month custodial sentence. Subsequently, these authorities decided to surrender Mr. West, in compliance with the aforementioned European arrest warrant, to the Finnish authorities,

\footnotetext{
${ }^{23}$ Cf. Djoheur Zerouki-Cottin, "Chronique de droit pénal de l'Union europénne, 1er janvier - 31 décembre 2012", Revue internationale de droit pénal, vol. 83, 2012/3, 519-545; Fabienne Gazin, "Chaîne de mandats d'arrêt européen", Europe, 8-9, Août 2012, 313.
} 
having previously requested their consent to the United Kingdom authorities, who granted it without subjecting the surrender to any conditions.

Mr. West was surrendered to the Finnish authorities to serve the custodial sentence to which he had been convicted. The release of Mr West was scheduled for 29 April 2012, however, the Finnish authorities, on 17 February 2012, decided to surrender him to the French authorities to serve the custodial sentence to which he had been convicted, having obtained for this purpose the authorization of the Hungarian authorities. The British authorities had also been requested, but did not respond, therefore not allowing the surrender of Mr. West. He appealed the decision to surrender and the court of appeal decided to refer a question to the Court of Justice on the interpretation of Article 28(2) of the Framework Decision.

The referring court asked whether, «in applying Article 28(2) of the Framework Decision, does 'executing Member State' mean the Member State from which a person was originally surrendered to another Member State on the basis of a European arrest warrant, or that second Member State from which the person was surrendered to a third Member State which is now requested to surrender the person onward to a fourth Member State? Or is consent perhaps required from both Member States?».

Whereas, initially, the Court of Justice considered to be competent to hear the matter referred to it in accordance with Article 10(1), of Protocol No 36 on transitional provisions, being Framework Decision 2002/584/JHA applicable to the case in point, since none of the Member States concerned made the statement referred to in Article 32 of the Framework Decision, the Court of Justice decided to rephrase the question posed, considering that what was asked, in essence, was whether Article 28(2) of the Framework Decision must be interpreted as meaning that, «where a person has been subject to more than one surrender between Member States pursuant to successive European arrest warrants, the subsequent surrender of that person to a Member State other than the one which last surrendered him is subject to the consent of the Member State which carried out his initial surrender, to the 
consent of the Member State which carried out his last surrender or to that of each of the surrendering Member States».

The Court of Justice held that «Article 28(2) of Council Framework Decision 2002/584/JHA (...), as amended by Council Framework Decision 2009/299/JHA (...), must be interpreted as meaning that, where a person has been subject to more than one surrender between Member States pursuant to successive European arrest warrants, the subsequent surrender of that person to a Member State other than the Member State having last surrendered him is subject to the consent only of the Member State which carried out that last surrender».

In this regard, the Court of Justice based its reasoning primarily on two reasons. As is apparent from recital 49 of the judgment, the Court of Justice focused its analysis on the wording of Article 28 (2) (literal element), and took into account the objective of the Framework Decision (teleological element). Regarding the literal element, the Court of Justice noted that the legal provision in question does not explicitly address the situations, such as the one at hand in the main proceedings, in which a person is the subject of three requests for successive surrenders, considering, however, that the term «executing Member State» refers to the Member State which carried out the European arrest warrant under which the person concerned was surrendered to the issuing Member State, conferring that Member State with the power to surrender this person, as executing Member State, to another Member State.

As regards the teleological element, it is further examined in the Judgment in question. Referring to the previous case law, the Court of Justice notes that the Framework Decision aims, inter alia, to facilitate and to accelerate judicial cooperation (cf. Advocaten woor de Wereld, Santesteban Goicoechea, and Leymann and Pustarov Judgments, abovementioned), contributing to the achievement of the objective of the European Union to become an area of freedom, security and justice, founded on a high level of confidence between Member States (cf. Judgment Leymann and Pustarov). Thus, the Framework Decision is to replace the multilateral system of extradition between Member States by a 
system of surrender between judicial authorities of convicted persons or suspects of practicing crimes, with the system of surrender being based on the principle of mutual recognition (cf. Advocaten woor de Wereld, Koslowski, Wolzenburg, Mantello Judgments).

This principle, the cornerstone of judicial cooperation, implies that Member States must, in principle, execute a European arrest warrant, but they must only subject the execution to the conditions listed in Articles 3 to 5 of the Framework Decision. Similarly, in accordance with Article 28 (3) of the Framework Decision, the consent for a subsequent surrender may only be refused under the same conditions (cf. Leymann and Pustarov, Wolzenburg, Mantello Judgments). The Court of Justice held that requiring consent from the first executing Member State and also the second, could, therefore, undermine the purpose of the Framework Decision to accelerate and simplify judicial cooperation between Member States, given the possibility for Member States to express multiple requests for additional information, as well as to increase divergent decisions regarding the surrender of the person concerned. The Court of Justice also considered, in favour of achieving the objectives of simplicity and rapidity of judicial cooperation, that the second and third executing Member States have a more direct and immediate relationship facilitating the assessment of the situation of the person concerned.

Thus and on the one hand, considering that the term «executing Member State» refers solely to the Member State which granted the last surrender, enhances the system of surrender established by the Framework Decision in favour of an area of freedom, security and justice in accordance with the mutual trust that must exist between Member States. On the other hand, by limiting the situations where the Member States involved in the surrender of a person might refuse their consent to the subsequent execution of a European arrest warrant, it facilitates the surrender of requested persons, in accordance with the principle of mutual recognition set out in Article 1 (2) of the Framework Decision, which constitutes the essential rule of this law (cf. Judgment Wolzenburg).

It is true that the principle of mutual recognition does not imply an absolute obligation to comply with the European arrest warrant, but Member States, pursuant to Articles 3 to 5 of 
the Framework Decision, may allow the competent judicial authorities to refuse to execute a surrender (cf. Judgment B.). Article 28 (2) must be understood in this context: both during the execution of the first European arrest warrant, and when requesting consent to the execution of the surrender of the person concerned, the executing Member State could rely, pursuant to Article 28 (3), on the provisions set out in Articles 3 to 5 of the Framework Decision.

Thus, the interpretation of the term «executing Member State» as reported to the Member State which executed the last surrender does not undermine the competences of the first executing Member State. This reasoning is extended to the solution of the issues raised regarding the further verification of the hypotheses provided in Articles 3 to 5, furthermore the Court of Justice rejected the possibility that the interpretation advocated might harm the person in question since, considering the high degree of trust between Member States on which the economy of the Framework Decision rests, it is up to the further executing Member States to assess the fulfilment of the requirements for applying Articles 3 to 5 and invoke them if necessary, refusing to surrender the person.

In conclusion, in an intermediate manner regarding these matters, the Court of Justice recalls that, since Articles 27 and 28 of the Framework Decision establish rules derogating from the principle of mutual recognition set out in Article 1(2) of the Framework Decision, they may not be construed so as to neutralize the purpose of the Framework Decision to facilitate and accelerate surrenders between judicial authorities of the Member States in view of the mutual trust that must exist between them.

The analysis of the Judgment West allows to claim that the Court of Justice has largely contributed to the affirmation of the principle of mutual recognition which underpins the Framework Decision 2002/584/JHA, giving consistency to the mutual trust on which the cooperation between Member States is founded. In fact, as is apparent from the foregoing, the arguments related to the protection of the prerogatives of the Member States, reflected in Articles 27 and 28, were removed with the use of the objective of the Framework Decision to facilitate and accelerate the surrender of convicted persons or suspects in the 
context of a legal system that is based on mutual trust between Member States and on the principle of mutual recognition, flagged in the cornerstone of judicial cooperation. While considering all the arguments presented by the parties in the process, indicated in the judgment, the Court of Justice gave clear preference to those who perform the mentioned objective in the most efficient way, thereby helping to build the area of freedom, security and justice that the Union intends to become.

\section{Arrest warrant and urgent preliminary ruling procedure}

1. Most decisions of the Court of Justice concerning the Framework Decision 2002/584/JHA are by the Grand Chamber, with the exception of four of them, and, with regard to three of the cases, they were processed in accordance with the urgent preliminary ruling procedure, in force since 2008. These are the cases which gave rise to the Santesteban Goicoechea, Leymann and Pustarov and West Judgments.

In fact, since $1^{\text {st }}$ March 2008, the Court of Justice has a new procedural tool that allows it to decide preliminary rulings relating to the currently named area of freedom, security and justice (AFSJ) within shorter time frames than the ones generally provided for a preliminary ruling in accordance with the requirements of speed that might be set out for the areas covered.

Under Article 107 (1) of the Rules of Procedure of the Court of Justice a «reference for a preliminary ruling which raises one or more questions in the areas covered by Title $\mathrm{V}$ of Part Three of the Treaty on the Functioning of the European Union may, at the request of the referring court or tribunal or exceptionally, by the Court's own motion, be dealt with under an urgent procedure derogating from the provisions of these Rules». ${ }^{24}$

\footnotetext{
${ }^{24}$ The current Rules of Procedure of the Court of Justice that are published in OJ L 265/1 (09.29.2012) have been rectified under publication in OJ L 274/34. After the Conference to honour Cunha Rodrigues the Rules of Procedure were amended on 18 June 2013, and this amendment was published in OJ L-173/65 (26.06.2013). Under Article 104-B (1) of the previous Rules of Procedure «a reference for a preliminary ruling which raises one or more questions in the areas covered by Title V of Part Three the Treaty on the Functioning of the European Union may, at the request of the referring court or tribunal or, exceptionally, of the Court's own motion, be dealt with under an urgent procedure derogating from the provisions of these Rules».
} 
The consecration of this procedure results from the initiative of the Court of Justice which, anticipating the changes that would be adopted in the Lisbon Treaty, proposed to the Council, in September 2006, a discussion paper - which was completed in December of the same year by a document which included the need to implement an urgent procedure in the area of freedom, security and justice. In these documents the Court of Justice proposed two solutions - and the Council has opted for one that guarantees the participation of all Member States in the oral procedure. Following this Decision of the Council of 20 December 2007, ${ }^{25}$ which modified the Protocol on the Statute of the Court of Justice, Article 23 bis of the Statute of the Court was introduced, as a result, its Rules of Procedure have been amended, in order to introduce the procedural provisions concerning the urgent preliminary ruling procedure.

2. The scope of the urgent preliminary ruling procedure is materially circumscribed, even though it is intended to evolve according to the intensity of the activity of the Union legislator. Indeed, the urgent preliminary ruling procedure was devoted to the areas to which Articles 29 to 42 of Title VI of the Treaty on European Union and Articles 61 to 69 of Title IV of Part Three of the Treaty establishing the European Community refer to, as regards, respectively, to police and judicial cooperation in criminal matters and visas, asylum, immigration and other policies related to the free movement of persons, including cooperation in civil matters. With the entry into force of the Lisbon Treaty on 1 December 2009, such matters are dealt with in Title V of Part Three of the TFEU.

These themes are grouped under the heading Area of Freedom, Security and Justice (AFSJ), formerly named Justice and Home Affairs (JHA). This is the first condition for the application of the urgent preliminary ruling procedure. Regarding the second condition, it derives from the urgency - that is, the need for urgent treatment of interpretational issues. Thus, Article 107 (2) of the Rules of Procedure requires the referring court to set out «the matters of fact and law which establish the urgency and justify the application of that exceptional procedure».

\footnotetext{
${ }^{25}$ OJ L 24 of 29 January 2008, 39.
} 
The Rules of Procedure do not contain any indication concerning the urgency, not specifying what is likely to constitute the urgency. However, the Declaration of the Council accompanying the decision amending the Protocol on the Statute of the Court of Justice ${ }^{26}$ sets out its concerns, and some auxiliary elements of interpretation may be found there. In this declaration the Council refers to situations where the urgency results from short deadlines imposed by national legislation or Union law or the serious implications for the people involved.

Furthermore, the Court of Justice published an explanatory note on its website ${ }^{27}$ containing references indicating disputes relating to persons detained or deprived of their liberty, as well as those persons which are involved with parental responsibilities or childcare issues. In fact, the first procedures that ran under this form of process remain within the lines drawn by these documents and seem to devote a relatively demanding interpretation of the criterion of urgency. ${ }^{28} 29$ The Court has attached particular importance to the fact that the person involved in the procedure may or may not be detained or deprived of liberty which is somewhat symptomatic with what was decided in the judgment analysed relating to $\mathrm{Mr}$. West, since he was about to be released, as his sentence was coming to an end, when the

\footnotetext{
${ }^{26}$ OJ L 24 of 29 January 2008, 44.

${ }^{27}$ Previously, OJ C-64/1 of 3 March 2008 and OJ C-160/1 of 28 February 2011. Currently, OJ C-338/1 of 6 November 2012.
}

${ }^{28}$ The first case in which the Court of Justice made use of this urgent procedure gave rise to the Judgment Rinau, 11 July 2008, Case C-195/08 PPU and then curing the recognition of a decision on the return of a child wrongfully retained by a parent in a Member State other than the onein which he resided. The Court of Justice agreed to use the urgent procedure given the deadline of six weeks prescribed in this matter by Regulation (EC) 2201/2003, 27 November 2003, and in order to avoid the degradation of the relationship of the minor with the parent from which he was estranged that could involve irreparable damage to that relationship.

${ }^{29}$ In the Judgment Santesteban Goicoechea, 12 August 2008, Case C-296/08 PPU the apparent urgency resulted from the need to release the applicant who was being held within the scope of an extradition procedure. In Judgment Leymann and Pustarov, 1 December 2008, Case C-388/08 PPU the urgency stemmed from the influence of the interpretation sought in the arrest of the individuals concerned, since it could determine their immediate release. In Judgment Kadzoev, 30 November 2009, Case C-357/09 PPU the proceedings concerned the interpretation of Directive 2008/115/EC, 16 December 2008, on common standards and procedures in Member States for returning illegally staying third-country nationals, being Mr. Kadzoev detained without knowing whether he should remain in this situation given that the interpretation lacked by the referring body. In the Judgment Detiček, 23 December 2009, Case C-403/09 PPU the case concerned a child whose custody was questioned, and the urgency was founded upon the fact that the delay of the decision could lead to the irreparable deterioration of the child's relationship with his father. 
preliminary ruling was referred to the Court of Justice. The cases processed in this manner involved persons deprived of liberty, either because they were arrested, or were under an inpatient in a health facility, or were even being held under charges of illegal entry into the Union. ${ }^{30}$

3.1. As regards the legitimacy to request the application of the procedure corresponding to the urgent preliminary ruling procedure, it is up to the national court to make a request to that effect. However, Article 107(1) of the Rules of Procedure provides that the Court may exceptionally order this form of process, under proposal by the President, as is apparent from paragraph 3 of Article 107.

The Recommendation of the Court of Justice (former Explanatory note) suggests the referring court to formulate the request for adoption of this urgent procedure unambiguously and that it may do so upon a separate request, allowing the Registry of the Court (Greffe), to be alerted from the ouset to the urgent situation, so as to give priority and proper treatment. The note also recommends the referring court to indicate the answer that it proposes to the question referred in order to facilitate the definition of the position of the parties who will be involved in the process.

3.2. Concerning its organization the urgent preliminary ruling procedure differs from other procedures in three key aspects:

- firstly, the processes will be handled by the Chamber appointed for this purpose for a period of one year;

\footnotetext{
${ }^{30}$ In the Judgment Vo, 10 April 2012, Case C-83/12 PPU concerning the interpretation of Articles 21 and 34 of the Community Code on Visas, the issue was the possible release of a Vietnamese citizen serving a custodial sentence as a result of the interpretation of these rules. In the Judgment Health Service Executive, 26 April 2012, Case C-92/12 PPU concerning the interpretation of Articles 1, 28 and 56 of Regulation (EC) 2201/2003, 27 November 2003, on jurisdiction and the recognition and enforcement of judgments in matrimonial matters and in matters of parental responsibility, when the minor, the applicant in the proceedings, was hospitalized against his will in a health care facility, almost coming of age and at risk, and whose hospitalization depended on the interpretative responses to be provided by the Court of Justice. In the Judgment Adil, 19 July 2012, Case C-278/12 PPU where Articles 20 and 21 of the Schengen Borders Code were interpreted, the urgency was connected with the fact that the Court of Justice's answers to the questions placed by the referring court could determine the immediate release of Mr. Adil, who was detained due to his irregular entry into the territory of the Union.
} 
- secondly, the urgent preliminary ruling procedure is characterized by the consistent decoupling procedure in the submission of oral and written procedures and different rules regarding the parties that may intervene; and,

- thirdly, this procedure requires speed which led to innovation and flexibility in the communications between the Court and the other procedural contributors, as well as in the working methods.

3.2.1. The attribution of the handling of urgent preliminary ruling procedures to a single Chamber designated for this purpose for a period of one year, aims to ensure a certain consistency in the urgent treatment, as well as effectiveness in applying the procedure.

The Chamber thus assumes a role in the filtering and formation of the hearing - in fact, it is for the chamber in question to take all necessary and useful decisions to the conduct of the procedure, from the initial stage of the decision on the approval or not of an urgent procedure until the delivery of the final judgment, to the measures for the investigation of the case involving the organization of the written and oral procedures.

Where appropriate, the Chamber may decide to refer the case to a reduced formation of three judges or, conversely, it may decide to refer the case to the general meeting with a view to its attribution to a larger formation (Grand Chamber, composed of 13 judges, as in the Kadzoev case).

3.2.2. The differentiation of treatment existing between written and oral procedures reflects the balance sought by the Council with the consecration of the urgent preliminary ruling procedure - compromise between the need to ensure rapid processing of the cases in question and the preservation of certain fundamental features of the preliminary ruling.

Thus, unlike what prevails in the ordinary preliminary ruling, participation in the written procedure is reserved for the parties in the proceedings pending before the national court, the Member State of the national court as well as the European Commission and the institutions that produced the act subject to the sought interpretation. Initially, only those 
persons shall be notified of the order for reference in order to prepare their written observations. From the point of view of speed, as all parties authorized to intervene submit comments on the language of the proceedings, the Court of Justice quickly starts the procedure with a notification of the order for reference without curing its translation in the other official languages of the Union. Moreover, the workload of the translation services is relieved, since all documents are written in one language only.

Always bearing in mind the need for swift processing of the case, the Chamber has the power to fix the time within which the written observations will be presented, as well as fix the number of pages in which they should be contained and clarify the points which the Parties shall address in particular. Under Article 111 of the Rules of Procedure, the Chamber may decide, in cases of extreme urgency, to waive the written procedure referred to in Article 109 (2). The Court of Justice had envisaged the suppression of the written procedure with the aim of reducing the duration of the procedure. However, considering the specificity of the matters under discussion and the fragility of the interests of the persons concerned, it was considered that if only a hearing was to be held, it would not provide sufficient guarantees regarding the right to be heard.

Contrary to the written procedure, the oral procedure is open to all parties covered by Article 23 of the Statute of the Court of Justice, therefore including all the Member States. To this end, they receive a translation of the order for reference that has since taken place, as well as the text of the observations presented in the written procedure. After holding the hearing, the formation of the Court meets, usually in the same day, to discuss, after hearing the Advocate General, who presents no formal conclusions, presenting its position orally to the formation of the Court, in an administrative meeting held for that purpose. The position of the Advocate General is usually developed in a written document which may be published alongside the judgment.

3.2.3. The speed requirements demand the use of electronic means in the communication between the Court of Justice, the courts and the parties. 
Thus, in its Recommendation the Court invites the national courts to use e-mail subject to the later consignment of the originals. The procedure begins with the receipt of the electronic version and the mandatory period of 10 days for the deposit of the originals provided in article 57 (7) for the ordinary preliminary ruling is inapplicable here. Notices and communications that the Court may issue in this type of procedure will be implemented by the same electronic manner. From the practical point of view, due to the said requirements, there are specially organized shifts for the different services of the Court, video conferencing systems are available and separate IT circuits.

4. A distortion of the preliminary ruling was feared, one which does not happen in practice for, in very short notice, the Court has taken decisions on complex issues in very recent or new areas, being well-informed decisions, it can be said that the results are promising. Presently, there are concerns about the success of the procedure and on the excess of service for the chamber due to the enlargement of its scope resulting from the entry into force of the Lisbon Treaty. However, it should be noted that the Chamber may make use of the possibility to rule by a simple order, accepting that the accelerated procedure may be used more often, the position taken by the Advocate General may also be dispensed or the working methods may be reformed.

5. It is important to distinguish the urgent procedure mentioned from the expedited preliminary ruling procedure currently provided for in Article 105 of the Rules of Procedure of the Court of Justice. This procedural tool was introduced in the year 2000 and provides a shortening of the ordinary terms of the classic preliminary ruling. The expedited treatment can only be granted by the President of the Court of Justice at the request of the referring court, in exceptional circumstances, «where the nature of the case requires that it be dealt with within a short time». This requirement explains why the Court has granted this procedural treatment in very few cases but it is nevertheless applicable to most areas of Union law. 


\section{Conclusion}

The principle of mutual recognition and the high degree of trust between the Member States in which the system established by the Framework Decision 2002/584/JHA is founded upon have contributed decisively to foster closer cooperation among the Member States of the Union, this time in the sensitive field of criminal law. Undeniably, when one analyses the case law of the Court of Justice, it has been collaborating in this field to promote such cooperation, arising from the interpretation it has delivered on the rules of the Framework Decision, the streamlining and simplification of the mechanisms for the surrender of persons, making the European arrest warrant a «powerful instrument of judicial cooperation» in the words of Professors Figueiredo Dias and Pedro Caeiro. ${ }^{31}$

Through the European arrest warrant the circulation of judicial decisions in the field of criminal law has been asserted and enhanced, implementing a genuine European area of freedom, security and justice, fundamental to the upholding of the rights and freedoms of the citizens of the Union. This contribution ends with a reference to the speech by the French writer Victor Hugo in the Peace Congress held in Paris on 21 August 1849, which is believed to be highly topical in the crisis context, in particular, to strengthen the European ideal: «Un jour viendra où vous France, vous Russie, vous Italie, vous Angleterre, vous Allemagne, vous toutes, nations du continent, sans perdre vos qualités distinctes et votre glorieuse individualité, vous vous fondrez étroitement dans une unité supérieure, et vous constituerez la fraternité européenne (...) Un jour viendra où il n'y aura plus d'autres champs de bataille que les marchés s'ouvrant au commerce et les esprits s'ouvrant aux idées». ${ }^{32}$

\footnotetext{
${ }^{31}$ Cf. Jorge de Figueiredo Dias/Pedro Caeiro, "Comentário ao Acórdão Advocaten voor de Wereld VZW c. Leden van de Ministerraad", in Jurisprudência. Cunha Rodrigues - Comentários, ed. Eduardo Paz Ferreira et al. (Lisboa: AAFDL, 2013), 14-29.

${ }^{32} \mathrm{Cf}$. http://www.assemblee-nationale.fr/13/evenements/textes_victor_hugo.asp
} 